\title{
Molecular barcoding of marine ornamental fish from the southern coast of West Java validates conventional identification
}

\author{
Agus Nuryanto ${ }^{1, *}$, Kusbiyanto Kusbiyanto ${ }^{1}$, Dian Bhagawati ${ }^{1}$ \\ ${ }^{1}$ Biology Faculty, Jenderal Soedirman University, Purwokerto 53122, Central Java, Indonesia
}

\begin{abstract}
Conventional identification of marine ornamental fish has faced difficulties due to similar color patterns of closed related species, or juvenile individuals have different color patterns from adult individuals. Molecular barcoding using the cytochrome c oxidase I (COI) gene provides a reliable tool for unmasking such difficulties. This study aimed to barcode marine ornamental fish from the southern coast of West Java. Fragment of the COI gene was sequenced from 54 morphotypes. In this study, we determined the taxonomic status of the samples based on a $5 \%$ genetic divergence, with the parameter including sequence percent identity, genetic distance, and length of monophyletic branch in a phylogenetic tree. The result showed that most samples had a high percentage of sequence identities, low genetic distances, and short chapters in monophyletic clades, but the remaining were not. Those data indicated that most samples could be identified at species-level without doubt and support conventional identification. Barcoding success is also depending on the availability of conspecific sequences in the databases. This study concluded that molecular barcoding could strengthen and validate traditional identification.
\end{abstract}

\section{Introduction}

Indonesian coral reef supports consumptive and non-consumptive fish species. Ornamental fish is a non-consumptive fish group that is utilized for recreation. This fish group is in high demand because of its beautiful colors and color pattern, both in juvenile and adult individuals. Ornamental fish has a broad market from national to international trading [1].

Trading of these wildlife commodities in Indonesia has been started since the 1990s either local or international trade. Many publications have reviewed the ornamental marine fish from Indonesia. However, mainly on trading values and data were collected from prominent exporters [1-3]. The study focused on species diversity of marine ornamental fish on particular sites where the commodities are collected relatively rare, especially on the southern coast of West Java. Data on marine ornamental fish production at the south coast of West Java were also not available.

\footnotetext{
* Corresponding author: agus.nuryanto@unsoed.ac.id
} 
Two recent studies reported marine ornamental fish from the southern coast of West Java, which collected ornamental fish from Pangandaran [4] and Pelabuhan Ratu, Ujung Genteng, and Taman Manalusu [5]. In both studies, the researchers proved that the high species diversity of marine ornamental fish is involved in the aquarium trade on the southern coast of West Java.

In particular of ornamental fish groups, species identification mainly relied on morphological characters, such as color pattern faced difficulties and might lead to misidentification. On the one hand, closed related fish species might show only subtle morphological differences [6]. Different fish species might show similar colors and patterns in marine ornamental fish during the juvenile stage [7]. On the other hand, different life stages of ornamental fish offer different color and color patterns, such as Pomacanthus semicircular [8].

In addition to morphological characters, this report utilized molecular characters for species identification of marine ornamental fish from the southern coast of West Java. This study used the cytochrome c oxidase 1 (COI) gene as a barcode marker. The COI gene has been a reliable technique for species-level identification $[9,10]$. Some exceptions in some fish groups, COI barcodes could not differentiate closely related species [11]. Moreover, studies demonstrated that COI barcoding could reveal that cryptic species are also abundant $[12,13]$. Other studies also proved that COI barcoding was strengthened and validated morphological identification [6].

The researchers utilized variable sequence homology values during species delimitation. A minimum sequence homology of $97 \%$ or $3 \%$ sequence divergences is used for species delimitation in Boldsystems [14]. A similar value was also used by previous studies [15, 16] Ward et al. (2009) and Amatya (2019). Other researchers used a minimum of $98 \%$ sequence homology as species threshold. However, low genetic homology (below 95\%) was observed when the reference species came from different localities [17], while other studies used 99\% homology for species determination [18]. At the same time, many studies also reported that intraspecific genetic distances in fish were wildly variable among species ranging from 0.0 to higher than 0.05 [19, 20, 21, 22, 23]. Higher genetic distance among species was reported when considering the geographic localities of the samples [24]. Another study said that an overlap genetic distance is observed between intra- and interspecific individuals [25].

This study aimed to identify marine ornamental fish collected on the southern coast of West Java based on cytochrome c oxidase one gene barcoding to validate morphological identification

\section{Materials and methods}

\subsection{Sampling sites and times}

A total of 367 ornamental fish samples were bought from the first collector in Pelabuhan Ratu and Ujung Genteng, Sukabumi Regency, Taman Manalusu Garut Regency, and Bojongsalawe Village, District of Parigi, Pangandaran Regency (Figure 1). Ornamental fish samples were collected during the field trips in 2018 and 2019. 


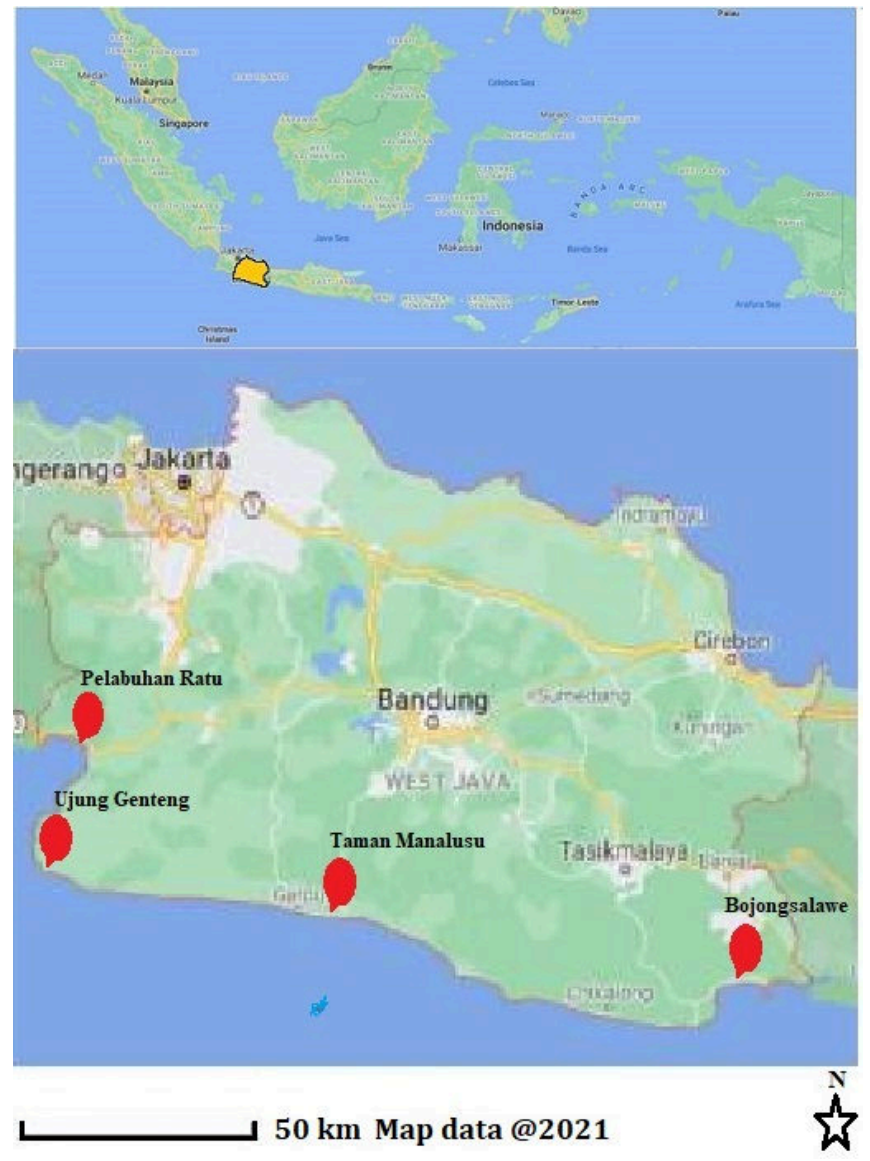

Fig. 1. Indonesia map indicates four sampling sites on the southern coast of West Java (Google mapmodified).

\subsection{Marker amplification and sequencing}

Molecular barcoding was carried out on 54 morphotypes identified morphologically. However, the results were questionable due to overlapping characters between closely related species. The genomic DNA of the samples was isolated from caudal fin clips using Chelex®100 methods [26] with slight modification [27]. The selected marker was amplified using primers FishF2 and FishR2 [28]. Reagent composition was as follow; 10X PCR buffer $5 \mu \mathrm{l}, \mathrm{MgCl}_{2}(50 \mathrm{mM}) 5 \mu \mathrm{l}, 2 \mu \mathrm{l}(0.01 \mathrm{mM})$ of each primer, $2 \mu \mathrm{l} \mathrm{dNTPs}$ $(0.05 \mathrm{mM}), 1 \mathrm{U}$ Taq polymerase, and $4 \mu \mathrm{l}$ of template DNA. Adjusted finale volumes to 50 $\mu 1$ were obtained by adding RNAse-DNAse free water.

The marker was multiplied using the following thermal cycles. Pre-denaturation was performed at $95^{\circ} \mathrm{C}$ for 5 minutes and continued by 35 cycles with the following conditions. The denaturation process was conducted at $94^{\circ} \mathrm{C}$ for 1 minute, annealing at a temperature range from $53^{\circ} \mathrm{C}$ to $55^{\circ} \mathrm{C}$ depending on the suspected species, and extension steps at $72^{\circ} \mathrm{C}$ for 1.5 minutes. We conducted the final extension for 5 minutes at $72^{\circ} \mathrm{C}$.

Half of the fish samples were treated as follows to obtain sequences data. The genomic DNA was isolated using ZR Tissue and Insect DNA Miniprep Kit (Zymo Research, D6016) following the protocol from the manufacturer. The PCR amplification of the selected COI marker was performed using the MyTaq HS Red Mix (Bioline, BIO-25047), 
while the sequencing of the COI gene was used in the bi-directional sequencing technique. All procedures of DNA analysis were conducted at Genetika Laboratory (PT. Genetika Science Indonesia).

\subsection{Sequences editing and species determination}

All the sequences were subjected to manual editing, and trimming using Bioedit 7.0 software packed [29]. With manual checking, pairwise multiple sequences alignment was conducted using ClustalW as applied in Bioedit 7.0 software packages [29]. The marker's confidence level as the actual COI sequence obtained from the translation process to the amino acid using the ORF Finder online version (https://www.ncbi.nlm.nih.gov/orffinder/). This study rechecked the translation results through the blast process with the formatting option search parameters plus the CDS feature. This process was carried out to ensure no stop codon in the middle of the COI gene base sequence is obtained.

We determined the taxonomic status of each morphotype based on the sequence identity or similarity value of $95 \%$. The present study chose that value based on a consideration that species could have other sequences divergences within species [6] and geographic locality between the current samples and the references species [17] available in the barcode library (GenBank and Boldsystems). The Kimura 2-parameter genetic distance of 0.05 was selected as additional data for species-level identification. Support to those values was also obtained from the phylogenetic tree, reconstructed based on 527 base pair (bp) sequences. The tree was constructed using the Neighbor-joining method based on the Kimura 2parameter substitution model. We obtained branching polarity from 1000 bootstraps pseudoreplication. Genetic distances calculation and tree reconstruction were performed in MEGAX [30]. Short branches in the monophyletic clade (maximum scale 0.05) were referred to as a single species. This study compared molecular barcoding with previous studies, which identified marine ornamental fish from the same sites but based on morphology $[4,5]$. That step was conducted to check the validity of morphological identification.

\section{Results and discussion}

\subsection{Results}

\subsubsection{Taxonomic status}

Sequence identity test using essential local alignment search tool (BLAST) to the references species available in GenBank resulted in identity values ranging from $94.65 \%$ to $100 \%$. This study also rechecked sequence similarities of the samples to conspecific references in Boldsystems. The current study obtained the lowest identity value of $94.65 \%$ for the sequence of WJM5. A detail data on sequence identity values and genetic distances between samples and their references species are presented in Table 1. 
Table 1. Sequences identity values and genetic distances between samples and conspecific references

\begin{tabular}{|c|c|c|c|c|}
\hline Samples & $\begin{array}{l}\text { Accession } \\
\text { number }\end{array}$ & $\begin{array}{l}\text { Identity } \\
\text { (\%) }\end{array}$ & $\begin{array}{l}\text { Genetic } \\
\text { distance }\end{array}$ & Conspecific references \\
\hline WJ01 & MK041042 & 99.19 & 0.009 & Myripristis hexagona JQ350118 \\
\hline WJ02 & MK041043 & 98.72 & 0.014 & Plectorhinchus picus FJ583866 \\
\hline WJ3Kc & MK256660 & 95.67 & 0.044 & Chaetodon vagabundus KJ967962 \\
\hline WJ04 & MK041044 & 100 & 0.000 & Hippocampus kuda GQ502154 \\
\hline WJ05 & MK256661 & 96.41 & 0.037 & Arothron hispidus JQ431462 \\
\hline WJ05GT & MK246805 & 96.70 & 0.032 & Acentrogobius nebulosus MK962523 \\
\hline WJ06 & MK041045 & 100 & 0.000 & Chaetodon kleinii MW034078 \\
\hline WJ07 & MK041046 & 99.16 & 0.008 & Chaetodon auriga MF123777 \\
\hline WJ08 & MK256662 & 99.52 & 0.005 & Dendrochirus zebra FJ583352 \\
\hline WJ08KKT & MK246806 & 98.02 & 0.018 & Chaetodon vagabundus JF434839 \\
\hline WJ09_01 & MK041047 & 100 & 0.000 & Chelmon rostratus FJ583127 \\
\hline WJ09 & MK256663 & 96.53 & 0.035 & Balistapus undulatus MN560967 \\
\hline WJ10 & MK246812 & 97.59 & 0.021 & Centropyge eibli KT001113 \\
\hline WJ10_1 & MK041048 & 99.35 & 0.006 & Dendrochirus zebra KF929813 \\
\hline WJ11DA & MK246807 & 96.73 & 0.033 & Dascyllus trimaculatus MF409512 \\
\hline WJ13 & MK041049 & 99.84 & 0.001 & Pterois miles $\mathrm{KU} 317873$ \\
\hline WJ14_1 & MK041050 & 100 & 0.004 & $\begin{array}{c}\text { Pomacanthus semicirculatus } \\
\text { FJ583886 }\end{array}$ \\
\hline WJ14 & MK246808 & 98.08 & 0.019 & Strophidon sathete MT318376 \\
\hline WJ15 & MK041051 & 99.69 & 0.004 & Chaetodon collare KC626015 \\
\hline WJ18 & MK256664 & 99.19 & 0.008 & Terapon jarbua FJ347886 \\
\hline WJM243 & MK246809 & 97.88 & 0.021 & Blenniella periophthalmus MF409604 \\
\hline WJM342 & MK246810 & 96.52 & 0.035 & Chaetodon decussatus GU673801 \\
\hline WJUG4 & MK246811 & 98.53 & 0.014 & Zanclus cornutus AP009162 \\
\hline WJM1 & MK256665 & 95.65 & 0.045 & $\begin{array}{c}\text { Neoglyphidodon boning FOAN677- } \\
\text { 11.COI-5P }\end{array}$ \\
\hline WJM4 & MK256666 & 98.69 & 0.013 & Naso unicornis JQ350128 \\
\hline WJM5 & MK256667 & 94.65 & 0.055 & Lutjanus decussatus KF009608 \\
\hline WJMG1 & MK256668 & 98.21 & 0.018 & $\begin{array}{c}\text { Plectroglyphidodon lacrymatus } \\
\text { KP194879 }\end{array}$ \\
\hline WJMG2 & MK256669 & 98.87 & 0.011 & Chaetodon rafflesii FJ583077 \\
\hline WJPR1 & MK256670 & 98.24 & 0.017 & Epinephelus merra MF185539 \\
\hline WJPR2 & MK256671 & 99.38 & 0.006 & Siganus guttatus KJ013064 \\
\hline
\end{tabular}




\begin{tabular}{|c|c|c|c|c|}
\hline Samples & $\begin{array}{l}\text { Accession } \\
\text { number }\end{array}$ & $\begin{array}{l}\text { Identity } \\
(\%)\end{array}$ & $\begin{array}{l}\text { Genetic } \\
\text { distance }\end{array}$ & Conspecific references \\
\hline WJPR3 & MK256672 & 97.98 & 0.020 & Sufflamen bursa MK657647 \\
\hline WJPR5 & MK256673 & 99.84 & 0.001 & Lutjanus fulvus KF009613 \\
\hline WJUG1 & MK256674 & 98.71 & 0.013 & Stethojulis trilineata JN313092 \\
\hline WJUG2 & MK256675 & 99.37 & 0.006 & Siganus spinus \\
\hline WJUG3 & MK256676 & 98.44 & 0.015 & Naso lituratus KC970406 \\
\hline PGN013 & MT881550 & 99.36 & 0.006 & Centropyge eibli KT001113 \\
\hline PGN014 & MT881551 & 100 & 0.000 & Acanthurus bariene KF009560 \\
\hline PGN015 & MT881552 & 100 & 0.000 & $\begin{array}{l}\text { Pseudobalistes flavimarginatus } \\
\text { MW034195 and MH331840 }\end{array}$ \\
\hline PGN021 & MT881553 & 99.84 & 0.001 & Chaetodon collare KX000917 \\
\hline PGN024 & MT881554 & 100 & 0.000 & Thalassoma lunare KF715032 \\
\hline PGN025 & MT881555 & 100 & 0.000 & Platax orbicularis MF123985 \\
\hline PGN_028 & MT881556 & 100 & 0.000 & Chaetodon lunula KP194718 \\
\hline PGN_030 & MT881557 & 99.84 & 0.001 & Ostracion cubicus JQ861019 \\
\hline PGN_702 & MT881558 & 100 & 0.000 & Sargocentron diadema MF409594 \\
\hline PGN_705 & MT881559 & 100 & 0.000 & Abudefduf vaigiensis JF434721 \\
\hline PGN_707 & MT881560 & 99.84 & 0.001 & Chaetodon ephippium MN733557 \\
\hline PGN_715 & MT881561 & 100 & 0.000 & $\begin{array}{l}\text { Balistoides viridescens KF025675 and } \\
\text { JQ431476 }\end{array}$ \\
\hline PGN_718 & MT881562 & 99.84 & 0.001 & $\begin{array}{c}\text { Sargocentron caudimaculatum } \\
\text { HM034164 }\end{array}$ \\
\hline PGN_719 & MT881563 & 99.84 & 0.000 & Pterois miles KU317873 \\
\hline PGN_728 & MT881564 & 99.84 & 0.000 & $\begin{array}{l}\text { Ostorhinchus novemfasciatus } \\
\text { FJ459573 and FADLI017-17.COI-5P }\end{array}$ \\
\hline PGN_729 & MT881565 & 99.35 & 0.000 & Scorpaenodes guamensis KU893076 \\
\hline PGN_819 & MT881566 & 99.84 & 0.000 & Pterois miles KU317873 \\
\hline PGN_828 & MT881567 & 99.84 & 0.000 & $\begin{array}{l}\text { Ostorhinchus novemfasciatus } \\
\text { FJ459573 and FADLI017-17.COI-5P }\end{array}$ \\
\hline PGN_924 & MT881568 & 99.84 & 0.001 & Thalassoma lunare KF715032 \\
\hline
\end{tabular}

The pairwise Kimura-2parameter (K2P) comparisons indicated that the samples had genetic distances between 0.000 and 0.055 (Table 1). We found the highest genetic distance of 0.055 between morphotype WJM5 and its references species Lutjanus decussatus. 


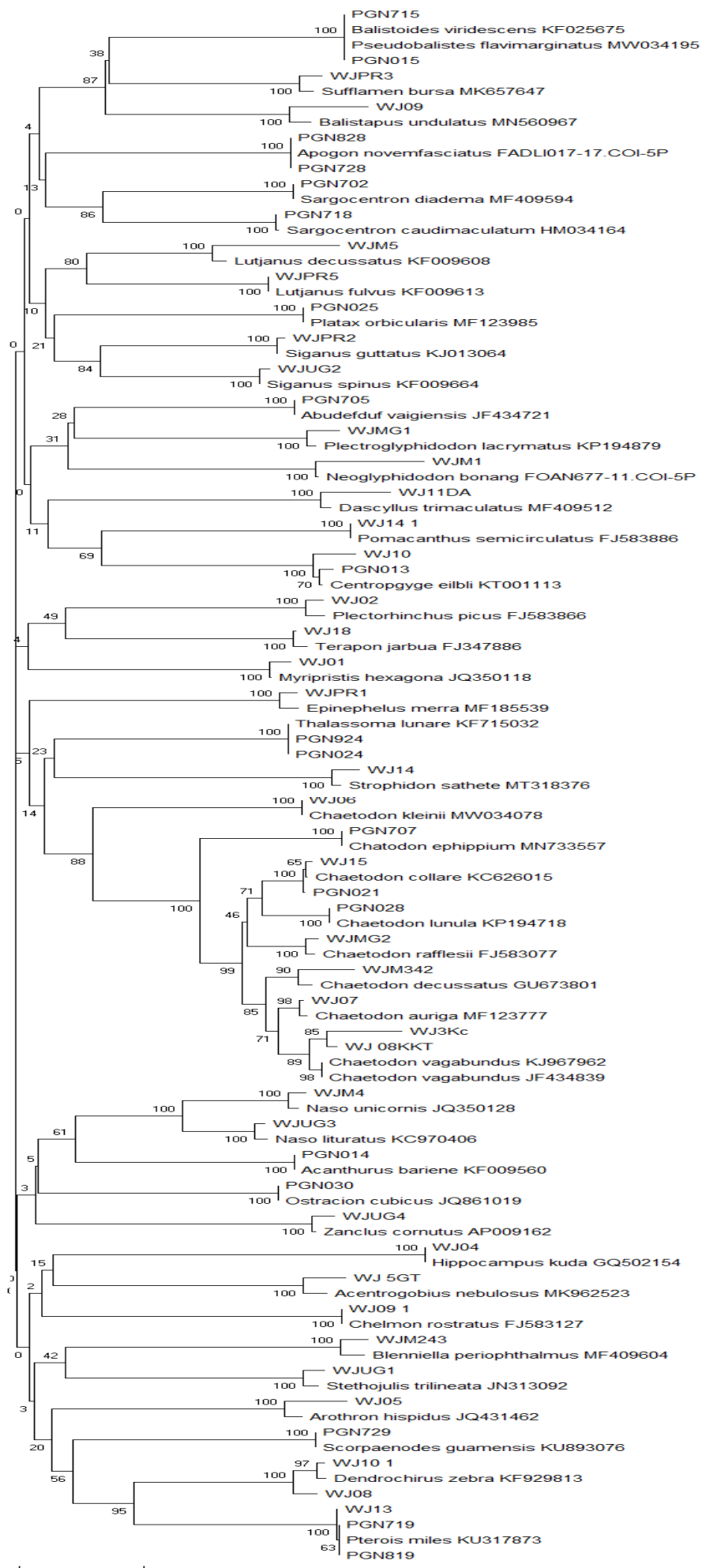

Fig. 1. Phylogenetic tree showing monophyly between samples and its references species. 
Neighbor-joining (NJ) phylogenetic tree reconstructed based on the K2P model indicated that most samples formed a monophyletic clade with their references species. Most representatives formed a clade with a short branch length to the references species except between WJM5 and L. decussatus. Almost all clade had branch lengths lower than 0.05 scales, and only WJM5 and L. decussatus clade had branch lengths higher than the 0.05 scale. The phylogenetic tree is presented in Figure 2.

\subsubsection{Molecular barcoding versus morphological identification}

Comparison to previous studies [2,5] proved that 51 out of $54(94.44 \%)$ morphotypes resulted in similar taxonomic status between molecular barcoding and conventional identification based on morphological characters. The remaining three morphotypes $(5.6 \%)$ were different between molecular and traditional identification. Complete data on the comparison between molecular barcoding and conventional identification is presented in Table 2.

Table 2. Molecular barcoding versus conventional identification

\begin{tabular}{|c|c|c|}
\hline Samples & Molecular barcoding & Conventional identification \\
\hline WJ01 & Myripristis hexagona & Myripristis hexagona \\
\hline WJ02 & Plectorhinchus picus & Plectorhinchus picus \\
\hline WJ3Kc & Chaetodon vagabundus & Chaetodon vagabundus \\
\hline WJ04 & Hippocampus kuda & Hippocampus kuda \\
\hline WJ05 & Arothron hispidus & Arothron hispidus \\
\hline WJ5GT & Acentrogobius nebulosus & Acentrogobius nebulosus \\
\hline WJ06 & Chaetodon kleinii & Chaetodon kleinii \\
\hline WJ07 & Chaetodon auriga & Chaetodon auriga \\
\hline WJ08 & Dendrochirus zebra & Dendrochirus zebra \\
\hline WJ08KKT & Chaetodon vagabundus & Chaetodon vagabundus \\
\hline WJ09_01 & Chelmon rostratus & Chelmon rostratus \\
\hline WJ09 & Balistapus undulatus & Balistapus undulatus \\
\hline WJ10 & Centropyge eibli & Centropyge eibli \\
\hline WJ10_1 & Dendrochirus zebra & Dendrochirus zebra \\
\hline WJ11DA & Dascyllus trimaculatus & Dascyllus trimaculatus \\
\hline WJ13 & Pterois miles & Pterois miles \\
\hline WJ14_1 & Pomacanthus semicirculatus & Pomacanthus semicirculatus \\
\hline WJ14 & Strophidon sathete & Strophidon sathete \\
\hline WJ15 & Chaetodon collare & Chaetodon collare \\
\hline WJ18 & Terapon jarbua & Terapon jarbua \\
\hline WJM243 & Blenniella periophthalmus & Blenniella periophthalmus \\
\hline WJM342 & Chaetodon decussatus & Chaetodon decussatus \\
\hline
\end{tabular}




\begin{tabular}{|c|c|c|}
\hline Samples & Molecular barcoding & Conventional identification \\
\hline WJUG4 & Zanclus cornutus & Zanclus cornutus \\
\hline WJM1 & Neoglyphidodon bonang & Neoglyphidodon bonang \\
\hline WJM4 & Naso unicornis & Naso brevirostris \\
\hline WJM5 & Lutjanus decussatus & Lutjanus decussatus \\
\hline WJMG1 & Plectroglyphidodon lacrymatus & Plectroglyphidodon lacrymatus \\
\hline WJMG2 & Chaetodon rafflesii & Chaetodon rafflesii \\
\hline WJPR1 & Epinephelus merra & Epinephelus merra \\
\hline WJPR2 & Siganus guttatus & Siganus guttatus \\
\hline WJPR3 & Sufflamen bursa & Sufflamen bursa \\
\hline WJPR5 & Lutjanus fulvus & Lutjanus bohar \\
\hline WJUG1 & Stethojulis trilineata & Stethojulis trilineata \\
\hline WJUG2 & Siganus spinus & Siganus spinus \\
\hline WJUG3 & Naso lituratus & Naso lituratus \\
\hline PGN013 & Centropyge eibli & Centropyge eibli \\
\hline PGN014 & Acanthurus bariene & Acanthurus maculiceps \\
\hline PGN015 & Pseudobalistes flavimarginatus & Pseudobalistes flavimarginatus \\
\hline PGN021 & Chaetodon collare & Chaetodon collare \\
\hline PGN024 & Thalassoma lunare & Thalassoma lunare \\
\hline PGN025 & Platax orbicularis & Platax orbicularis \\
\hline PGN_028 & Chaetodon lunula & Chaetodon lunula \\
\hline PGN_030 & Ostracion cubicus & Ostracion cubicus \\
\hline PGN_702 & Sargocentron diadema & Sargocentron diadema \\
\hline PGN_705 & Abudefduf vaigiensis & Abudefduf vaigiensis \\
\hline PGN_707 & Chaetodon ephippium & Chaetodon ephippium \\
\hline PGN_715 & Balistoides viridescens & Pseudobalistes flavimarginatus \\
\hline PGN_718 & Sargocentron caudimaculatum & Sargocentron caudimaculatum \\
\hline PGN_719 & Pterois miles & Pterois miles \\
\hline PGN_728 & Ostorhinchus novemfasciatus & Ostorhinchus novemfasciatus \\
\hline PGN_729 & Scorpaenodes guamensis & Scorpaenodes guamensis \\
\hline PGN_819 & Pterois miles & Pterois miles \\
\hline PGN_828 & Ostorhinchus novemfasciatus & Ostorhinchus novemfasciatus \\
\hline PGN_924 & Thalassoma lunare & Thalassoma lunare \\
\hline
\end{tabular}




\subsection{Discussion}

\subsubsection{Taxonomic status}

Fifty-three morphotypes had identity values above $95 \%$ to their conspecific references, with genetic distances below 0.05 (Table 1). Those morphotypes also formed monophyletic clades with branch lengths less than 0.05 to their conspecific references (Figure 2). Those three data (sequence identity, genetic distance, and branch length on monophyletic clade) proved that those 53 species could be assigned to species level. The assignment to the species level is defined according to the barcoding gap used in species determination is 5\% genetic divergence, which means $95 \%$ genetic similarity between query samples with conspecific references. Several studies reported that $95 \%$ could be used for species-level barcoding [17, 22-23]. The use of 3\% to 5\% genetic divergences must be added by other data [31], including geographic localities [32]. This study utilized the geographic localities of the samples and reference species as additional considerations for species determination.

There were exciting findings that two morphotypes had high sequence identities to two different references species. The PGN015 has 100\% to Pseudobalistes flavimarginatus and has $99.84 \%$ sequence identity to Balistoides viridescens. In contrast, PGN715 has an identity value of 100 to B. viridescens and $99.84 \%$ to Pseudobalistes flavimarginatus. In such a case, this study used the highest homology and the lowest genetic distances even though they formed a monophyletic clade with 0.00 branch length in the phylogenetic tree. Therefore, PGN015 and PGN715 were taxonomically referred to as P. flavimarginatus and $B$. viridescens, respectively. This situation was not surprising because previous studies also reported a similar condition in other fish groups [11]. They found a high homology value of Mystus vittatus sample to M. vittatus and M. horai in barcode databases ( $99 \%$ to each reference species, respectively). A similar high homology value was reported for Bagarius bagarius samples to $B$. vagaries and $B$. yarrelli in the databases, with homology values of $100 \%$ to both species, respectively [11].

Morphotype WJM5 had a sequence identity of $94.65 \%$ to 13 sequences of $L$. decussatus in GenBank and more than 50 sequences of L. decussatus in Boldsystems, genetic distance 0.055 , branch length was longer than 0.05 . The morphotype had sequence identity top hits to L. decussatus. However, because the used genetic gap was $95 \%$ sequences similarity and genetic gap 0.05, the morphotype WJM5 was referred to genus level Lutjanus and Lutjanus sp.

\subsubsection{Molecular barcoding versus morphological identification}

Based on the data in Table 2, the result of molecular identification was highly congruent $(94.44 \%)$ to conventional identification [4, 5]. High Congruent between molecular and morphological identification was reported in a previous study with success between $90 \%$ and $99 \%$ [33]. Congruent between morphological and molecular identification was also reported in mosquitoes [34].

In the case of WJM5, although it has 0.055 (higher than 0.05 ) genetic distance and genetic identity lower than $95 \%(94.65 \%)$, the nearest relative in barcode libraries (GenBank, 13 individuals, and Boldsystems, > 50 individuals) were L. decussatus. The result was congruence with conventional identification. It is reasonable that WJM5 had higher genetic divergence to its nearest relative in barcode libraries because the researcher collected from different geographic regions or even different oceans. This study collected samples from the southern coast of West Java (East Indian Ocean). In contrast, the previous researcher collected conspecific reference L. decussatus (KF009608) previously published in GenBank from the Philippines (Pacific Ocean). Combining both molecular and 
conventional identification for WJM5, we finally decided that WJM5 was referred to as $L$. decussatus. The argument was that samples of single species collected from different localities could have a relatively low genetic identity and high genetic distance to their conspecific references in barcode libraries [6, 17, 21-23, 31-32].

\section{Conclusions}

This study highlighted that under certain circumstances, molecular barcoding could strengthen and validate conventional identification. The success of species-level barcoding depends on the availability of conspecific sequences in databases.

\section{Acknowledgments}

We would like to thank the Directorate of Research and Community Service, Ministry of Research, Technology, and Higher Education for the funding with contract numbers: $1936 / \mathrm{UN} 223.14 / \mathrm{PN} / 2018$ and P/1811/UN23/14/PN/2019. We appreciate the head of Research and Community Service Institute and Dean of Biology Faculty of Jenderal Soedirman University, who provide administrative support during the project. Thank students who help during laboratory assessment of the fish samples.

\section{References}

1. C. Wabnitz, M. Taylor, E. Green, T. Razak, From ocean to aquarium (UNEP-WMP, Cambridge, 2003)

2. C. C. Shuman, G. Hodgson, R.F. Ambrose, Environ. Conserv. 31, 339-348 (2004)

3. V. Nijman, Biodivers. Conserv. 19, 1101-1114 (2010)

4. A. Nuryanto, D. Bhagawati, Kusbiyanto, Biodivers. 21, 512-520 (2020)

5. A. Nuryanto, D. Bhagawati, Kusbiyanto, IOP Conf. Ser. Earth Environ. Sci. 746, 012021 (2021)

6. S. Yi, J. Zhong, S. Huang, S. Wang, W. Wang, Biochem. Syst. Ecol. 70, 50-59 (2017)

7. R. Froese, D. Pauly, Fishbase, www.fishbase.org (2021)

8. G. R. Allen, M.V. Erdmann, Reef fishes of the East Indies I-III (University of Hawaii Press, Hawaii, 2012)

9. N. Hubert, C.P. Meyer, H.J. Bruggeman, F. Guerin, R.J.L. Komeno, B. Espiau, R. Caussee, J.T. Wiliams, S. Planes, PLoS One 7, 28987 (2012)

10. A. Karahan, J. Douek, G. Paz, N. Stern, A.E. Kideys, L. Shaish, M. Goren, B. Rinkevich, J. Nat. Conserv. 36, 1-9 (2017)

11. M. J. Bhattacharjee, B. A. Laskar, B. Dhar, S.K. Ghosh, PLoS One 7, 49950 (2012)

12. K. K. Dasmahapatra, M. Elias, R.I.Hill, J.I. Hoffman, J. Mallet, Mol. Ecol. Resour. 10, 264-273 (2010)

13. A. J. Guimaraes-Costa, F.S. Machado, R.R.S. Oliveira, V. Silva-Costa, M.C. Andrade, T. Giarrizo, U. Saint-Paul, I. Sampaio, H. Schneider, Sci. Rep. 9, 7530 (2019)

14. R. Ratnasigham, P. D. N. Hebert, Mol. Ecol. Notes 7, 355-364 (2007)

15. R. D. Ward, R. Hanner, P.D.N. Hebert, J. Fish Biol. 74, 329-356 (2009)

16. B. Amatya, Int. J. Biol. 11, 88-100 (2019) 
17. O. Abdalwahhab, A. Galal-Khallaf, S.A. El-Latif Saber, A.G.M. Osman, K. Mohammed-Geba, Aquat. Living Resour. 33, 10 (2020)

18. R. Hanner, S. Becker, N.V. Ivanova, D. Steinke, Mitochondrial DNA 22, 106-122 (2011)

19. L. H. G. Pereira, R. Hanner, F. Foresti, C. Oliveira, BMC Med. Genet. 14, 20 (2013)

20. M. Puckridge, N. Andreakis, S.A. Appleyard, R.D. Ward, Mol. Ecol. Resour. 13, 32$42(2013)$

21. J. Diaz, G.V. Villanova, F. Brancolini, F. del Pazo, V.M. Posner, A. Grimberg, S.A. Arranz, PLoS One 11, 0157419 (2016)

22. F. S. Ali, M. Ismail, W. Aly, Mol. Biol. Rep. 47, 5865-5877 (2020)

23. A. Sholihah, E. Delrieu-Trottin, T. Sukmono, H. Dahruddin, R. Risdawati, R. Elvyra, A. Wibowo, K. Kustiati, F. Busson, S. Sauri, U. Nurhaman, D. Dounias, M.S.A. Zein, Y. Fitriana, I.V. Utama, Z.A. Muchlisin, J-F Agnèse, R. Hanner, D. Wowor, D. Steinke, P. Keith, L. Rüber, N. Hubert, Sci. Rep. 10, 2818 (2020)

24. H. Asgharian, H.H. Sahafi, A.A. Ardalan, S. Shekarriz, E. Elahi, Mol. Ecol. Resour. 11, 461-472 (2011)

25. A. Bucklin, D. Steinke, L. Blanco-Bercial, Annu. Rev. Mar. Sci. 3, 471-508 (2011)

26. P. S. Walsh, D.A. Metzger, R. Higuchi, Biotechniques 10, 506-513 (1991)

27. A. Nuryanto, M. Kochzius, Coral Reefs 28, 607-619 (2009)

28. R. D. Ward, T.S. Zemlak, B.H. Innes, P.R. Last, P.D.N. Hebert, Phil. Trans. R. Soc. B 360, 1847-1857 (2005)

29. T. Hall, GERF Bull. Biosci 2, 60-61 (2011)

30. S. Kumar, G. Stecher, M. Li, C. Knyaz, K. Tamura, Mol. Biol. Evol. 35, 1547-1549 (2018)

31. N. W. Jefery, M. Elias-Guttierrez, S.J. Adamowicz, PLoS One 6, e18364 (2011).

32. R. Higashi, A. Tsukagoshi, H.Kimura, K. Kato, J. Crust. Biol. 31, 142-152 (2011)

33. R. A. Collins, K.F. Armstrong, R. Meier, Y. Yi, S.D.J. Brown, R.H. Cruickshank, S. Keeling, C. Johnston, PLoS One 7, 28381 (2012)

34. A. Chan, L-P. Chang, H.C. Hapuarachchi, C-H. Tan, S-C. Pang, R. Lee, K-S. Lee, LC. Ng, S-G. Lam-Pua, Parasites Vectors 7, 569 (2014) 